AperTO - Archivio Istituzionale Open Access dell'Università di Torino

\title{
How to interpret meta-analysis results
}

\section{This is the author's manuscript}

Original Citation:

Availability:

This version is available http://hdl.handle.net/2318/1645539

since 2018-10-31T17:26:43Z

Published version:

DOI:10.23736/S0031-0808.17.03323-7

Terms of use:

Open Access

Anyone can freely access the full text of works made available as "Open Access". Works made available under a Creative Commons license can be used according to the terms and conditions of said license. Use of all other works requires consent of the right holder (author or publisher) if not exempted from copyright protection by the applicable law. 
Comment on the paper by Hu et al.: how to interpret a meta-analysis result

\author{
Davide G. Ribaldone, ${ }^{1 *}$ Elisa Petrini ${ }^{2}$ \\ ${ }^{1}$ Unit of Gastroenterology, Molinette Hospital, Turin, Italy; ${ }^{2}$ General practitioner, Piedmont \\ Region, Italy
}

*Corresponding author: Davide Giuseppe Ribaldone, MD

Unit of Gastroenterology, Molinette-SGAS Hospital, Via Cavour 31, 10126 Turin, Italy

Phone.+39.011/6335208 E-mail: davrib_1998@yahoo.com

Key Words: Breast - Cancer - Meta-analysis - Polymorphism

Conflicts of interest.-The authors certify that there is no conflict of interest with any financial organization regarding the material discussed in the manuscript. 


\section{Dear Editor,}

Meta-analyses combine data and summarize the findings of several clinical trials or of research studies. In the last years the utilization of this statistical approach has increased both in clinical and in research setting. ${ }^{1-3}$ However, the interpretation of their data could vary among authors. In the last issue of Panminerva Medica we have read with interest the article by $\mathrm{Hu}$ et al, evaluating the association between PON1 (paraoxonase) L55M polymorphism and the presence of a cancer. Since the authors found an overall odds ratio (OR) of 1.21 (95\% confidence interval [CI]: 1.04 1.40) concluded that this polymorphism might increase the risk of cancer in general. In Table III the authors reported the data for neoplasm included by each study (prostate, breast, ovarian, lung and colorectal). Only in case of breast cancer the CI was $>1 .{ }^{4}$ Moreover, in this setting was included the study by Hussein et al, with an odds ratio $(\mathrm{OR})=6.35$ and a large CI (3.88-10.40). ${ }^{5}$ Hence, this could have unbalanced the overall result, considering also the results reported in Figure 2. ${ }^{4}$ CIs provide upper and lower limits that capture the range of values around the true but unknown population value. The $95 \% \mathrm{CI}$ is most commonly used and corresponds with the typical 5\% significance level used in hypothesis tests. It is accepted that CIs of continuous measures that include 0 represent non-significant results. CIs of ORs and relative risk that include 1.0 represent non-significant results. ${ }^{6}$

On the basis of these considerations we think that the conclusion of this meta-analysis should be that it has shown an association between PON1 (paraoxonase) L55M polymorphism and breast cancer and not cancer in general.

\section{REFERENCES}

1. Liu FT, Xue QZ, Zhu ZM, Qiu C, Hao TF, Zhu PQ et al. Long noncoding RNA PVT1, a novel promising biomarker to predict lymph node metastasis and prognosis: a metaanalysis. Panminerva Med 2016;58:160-6.

2. Ribaldone DG, Fagoonee S, Astegiano M, De Angelis C, Smedile A, Caviglia GP et al. 
Coxib's safety in patients with inflammatory bowel diseases: A meta-analysis. Pain Physician 2015;18:599-607.

3. Zhou Y, Zhang X, Gu C, Xia J. Diabetes mellitus is associated with breast cancer: systematic review, meta-analysis, and in silico reproduction. Panminerva Med 2015;57:101-8.

4. Hu P, Ma Y, Zhang L, Ma S. PON1 L55M polymorphism might contribute to the risk of cancer. Panminerva Med 2017;59:107-13.

5. Hussein YM, Gharib AF, Etewa RL, ElSawy WH. Association of L55M and Q192R polymorphisms in paraoxonas 1 (PON1) gene with breast cancer risk and their clinical significance. Mol Cell Biochem 2011;351:117-23.

6. Israel H, Richter RR. A guide to understanding meta-analysis. J Orthop Sports Phys Ther 2011;41:496-504. 